\title{
PENGEMBANGAN SENTRA PRODUKSI BIBIT (PENANGKARAN) KENTANG BERMUTU MELALUI APLIKASI TEKNOLOGI BIOSELULER DI KABUPATEN SOLOK
}

\author{
Irfan Suliansyah $^{1)}$, Helmi $^{2)}$, Budi Santosa ${ }^{3)}$, dan Fitri Ekawati ${ }^{4)}$ \\ ${ }^{1)}$ Fakultas Pertanian, Universitas Andalas, email: irfan.suliansyah@yahoo.com \\ ${ }^{2)}$ Fakultas Pertanian, Universitas Andalas, email: helmi59pdg@yahoo.com \\ ${ }^{3)}$ Fakultas Pertanian, Universitas Mahaputra Muhammad Yamin, email: budisolok@gmail.com \\ ${ }^{4)}$ Fakultas Pertanian, Universitas Muhammadiyah Sumatera Barat, emaill: fitri_ekawati@ymail.com
}

\begin{abstract}
ABSTRAK
Tujuan kegiatan ini adalah memberdayakan petani menjadi produsen bibit kentang unggul bermutu tinggi melalui alih teknologi bioseluler (kultur jaringan tanaman), sehingga petani dapat memenuhi kebutuhan bibitnya sendiri. Melalui kemampuannya untuk memproduksi bibit kentang bermutu, maka akan tercipta kegiatan di sektor penangkaran bibit kentang dan dapat meningkatkan pendapatan petani. Kegiatan terdiri atas tiga subprogram. Subprog $\neg$ ram pertama adalah produksi dan distribusi propagul kentang (umbi mini/G0) kepada petani penangkar (tahun pertama). Subprogram kedua adalah produksi umbi propagul kentang G1 G2 (Tahun kedua dan ketiga). Subprogram ketiga adalah sosialisasi, pembinaan, dan demonstrasi plot (setiap tahun). Kegiatan ini merupakan kemitraan antara Fakultas Pertanian Universitas Andalas, Fakultas Pertanian UMMY Solok, Dinas Pertanian Kabupaten Solok, dan Kelompok Tani Harapan Baru sebagai penggguna teknologi. Kegiatan yang sudah dilakukan pada Tahun I (2017): 1) perbanyakan planlet kentang, 2) pembuatan screen house untuk aklimatisasi dan produksi umbi G0/G1, 3) workshop/sosialisasi penangkaran benih kentang, 4) sekolah lapang produksi umbi kentang G0/G1, 5) pelatihan penguatan kelembagaan petani penangkar kentang, 6) pelatihan sertifikasi benih kentang, dan 7) pelatihan pembuatan pestisida hayati.
\end{abstract}

Kata Kunci: Bibit kentang, Penangkar, Bioseluler

\section{ABSTRACT}

The purpose of this activity was to empower farmers to become producers of elite potato seeds through the transfer of bioseluler technology (plant tissue culture), so that farmers can meet the needs of their own seeds. Through its ability to produce quality potato seeds, it will create activities in the breeding sector of potato seeds and can increase farmers' income. The activity consists of three subprograms. The first subprogram was the production and distribution of potato propagules (mini tubers/G0) to the farmer breeder (first year). The second subprogram was the production of potato propagules G1 - G2 (second and third year). The third subprogram is socialization, guidance, and demonstration plots (every year). This activity was a partnership between the Faculty of Agriculture Andalas University, Faculty of Agriculture UMMY Solok, Dinas Pertanian Kabupaten Solok, and Harapan Baru Farmer Group as a technology user. (1) propagation of potato plantlets, 2) screen house preparation for acclimatization and tuber production $G 0$ / G1, 3) workshop / socialization of potato seed breeding, 4) field school of potato tuber production $G 0 / G 1,5)$ training of institutional strengthening of potato breeder farmers, 6) certification training of potato seeds, and 7) training on making biological pesticides.

Keywords: Potato seeds, Breeder, Bioseluler 


\section{PENDAHULUAN}

Beberapa dekade yang lalu, Sumatera Barat terkenal sebagai salah satu sentra produksi kentang di Indonesia. Kabupaten Solok, merupakan salah satu kabupaten yang merupakan daerah/sentra produksi kentang dan menjadi pemasok kentang ke berbagai propinsi di sekitar Sumatera Barat. Bahkan juga pernah mengekspor hasil panen kentangnya ke beberapa negara tetangga. Sayangnya, julukan Sumatera Barat sebagai sentra produksi kentang dewasa ini hampir tidak pernah terdengar lagi. Para petani kentang secara berangsur mulai mengalihkan kegiatan usahataninya ke tanaman non kentang. Petani sadar bahwa dengan bertanam kentang, meskipun menjanjikan perolehan keuntungan yang berlipat, akan tetapi memiliki tingkat resiko yang tinggi pula.

Keengganan petani Sumatera Barat untuk membudidayakan kentang adalah sangat sulitnya mendapatkan benih kentang yang bermutu. Petani kentang umumnya mendatangkan benih dari Jawa Barat atau dari Sumatera Utara. Beberapa petani bahkan memperoleh benih dengan jalan impor.

Benih kentang merupakan sarana produksi utama dalam budidaya tanaman, dalam arti penggunaan benih berkualitas mempunyai peranan yang sangat menentukan dalam usaha meningkatkan produksi dan mutu hasil. Kebutuhan tersebut sebagian besar masih disuplai oleh benih dengan kualitas rendah. Hal ini menyebabkan produktivitas petani kentang di Indonesia masih rendah yakni hanya 15 17 ton per hektare. Sebagai pembanding, di Eropa bisa mencapai 50 ton per hektar (Jannah, 2016)

Faktor benih kentang bermutu hingga saat ini masih menjadi kendala utama bagi usahatani kentang. Petani umumnya belum menggunakan benih kentang secara khusus. Petani hanya menyisihkan sebagian umbi kentang panenannya yang berukuran kecil untuk digunakan sebagai benih pada pertanaman selanjutnya. Dengan cara tersebut, maka dapat dipastikan kualitas benih tersebut sangatlah rendah. Petani kentang di Alahan Panjang, Solok umumnya menggunakan kelas benih $\mathrm{G}_{6}, \mathrm{G}_{7}$, sampai $\mathrm{G}_{10}$. Pada kondisi tersebut, akumulasi penyakit dalam benih kentang yang terbawa secara sistemik sudah sedemikian banyaknya yang mengakibatkan tanaman terkena penyakit yang disebut penyakit degeneratif (Suliansyah, 1999).

Untuk mendapatkan benih bermutu, Indonesia masih mengimpornya dari luar negeri. Dari data statistika BPS diperoleh bahwa terdapat peningkatan volume impor benih dari tahun ke tahun. Apabila petani menggunakan benih impor, maka $40-50 \%$ dari total biaya produksi kentang sudah dikeluarkan hanya untuk pengadaan benih (Nugroho, 2011; Putra, 2008). Kondisi ini 
mengakibatkan petani yang umumnya berkemampuan ekonomi rendah tidak mungkin melakukannya. Di samping itu, karena benih berasal dari luar negeri yang kondisinya tentu berbeda mengakibatkan seringkali kurang sesuai dengan kondisi iklim di Indonesia.

Kebutuhan benih kentang saat ini ratarata per tahun sebanyak 108 ribu ton untuk area budidaya kentang seluas 72.000 hektare. Sedangkan ketersediaan benih kentang bersertifikat nasional saat ini baru mencapai 15 persen sehingga masih terbuka untuk memenuhi kebutuhan benih kentang dalam negeri (Ibrahim, 2017).

Untuk memperoleh benih kentang unggul dan bermutu dapat dilakukan melalui perbanyakan kultur jaringan (bioseluler). Aplikasi teknologi bioseluler selain bertujuan untuk perbaikan sifat tanaman, juga dimanfaatkan untuk pembebasan penyakit. Bahan tanaman yang telah terbebas dari penyakit tersebut selanjutnya dapat diperbanyak secara masal dalam waktu relatif singkat. Beberapa propagul yang dapat dikembangkan dari biosluler antara lain: umbi mikro, stek mikro, stek mini, dan umbi mini (Suliansyah, 1999).

Kabupaten Solok merupakan salah satu kabupaten di Provinsi Sumatera Barat yang beribu kota di Arosuka. Kabupaten ini secara geografis terletak antara 01 $20^{\prime} 27^{\prime \prime}$ $01^{\circ} 21^{\prime} 39^{\prime \prime}$ Lintang Selatan dan $100^{\circ} 25^{\prime}$ $00 "$ - $100^{\circ} 33^{\prime} 43^{\prime \prime}$ Bujur Timur. Topografi daerah Kabupaten Solok memiliki wilayah yang bervariasi antara dataran rendah sampai dataran tinggi, berada pada ketinggian 329 - 1.458 meter dari permukaan laut. Komoditas sayuran, kentang, bawang merah, kubis, cabai, dan sayuran jenis lainnya juga tumbuh sangat baik ini, terutama di dataran tinggi Alahan Panjang yang memiliki ketinggian rata rata di atas $700 \mathrm{~m}$ di atas permukaan laut (Anonimous, 2016).

Tujuan utama dari kegiatan ini adalah memberdayakan petani menjadi produsen benih kentang unggul bermutu tinggi melalui pembinaan dan alih teknologi produksi benih kentang bioseluler kepada petani, sehingga petani dapat memenuhi kebutuhan benihnya sendiri dalam kerangka usahatani kentang. Melalui kemampuannya untuk memproduksi benih kentang bermutu, maka akan tercipta lapangan kerja di sektor penangkaran benih kentang, sehingga dapat meningkatkan taraf hidup petani.

\section{METODE PELAKSANAAN KEGIATAN}

Seluruh kegiatan direncanakan dapat berlangsung dalam waktu tiga tahun. Kegiatan ini terdiri atas tiga subprogram kegiatan. Subprogram pertama adalah produksi dan distribusi propagul kentang bermutu (umbi mini $/ \mathrm{G}_{0}$ ) kepada petani (dilaksanakan pada tahun pertama). Subprogram kedua adalah produksi umbi propagul kentang $\mathrm{G}_{1}-\mathrm{G}_{4}$ (dilaksanakan 
pada tahun kedua dan ketiga) dengan pola usahatani kemitraan. Subprogram ketiga adalah sosialisasi, pembinaan, dan demonstrasi plot (dilaksanakan setiap tahun). Kegiatan ini merupakan kemitraan antara Fakultas Pertanian Universitas Andalas, Fakultas Pertanian Universitas Mahaputra Muhammad Yamin, Dinas Pertanian Kabupaten Solok, dan Kelompok Tani Harapan Baru sebagai pengguna teknologi.

Secara ringkas tahapan kegiatan yang akan dilaksanakan pada tahun pertama adalah produksi planlet in vitro yang dilakukan di Laboratorium Kultur Jaringan, Jurusan Budidaya Pertanian, Fakultas Pertanian, Universitas Andalas. Planlet selanjutnya diaklimatisasi dan digunakan untuk memproduksi setek mini. Langkah berikutnya adalah produksi G0 di screen house. Seluruh pelaksanaan kegiatan dari aklimatisasi hingga produksi G0 dilakukan di sentra produksi kentang di Kabupaten Solok. Pada tahun kedua akan dilakukan produksi bibit kentang $\mathrm{G}_{1}$ hingga $\mathrm{G}_{2}$. Selanjutnya pada tahun ketiga bibit tersebut digulirkan melalui program kemitraan dengan kelompok tani hingga $\mathrm{G}_{4}$. $\mathrm{Umbi}_{4}$ inilah yang kemudian dapat dijadikan umbi bibit untuk memproduksi umbi kentang konsumsi.

Kegiatan yang dilaksanakan pada Tahun 2017 ini terdiri atas:

Penentuan Lokasi. Lokasi awal yang akan ditentukan adalah lokasi sebagai tempat produksi setek mini dan umbi kentang $\mathrm{G}_{0}$. Pemilihan lokasi didasarkan atas kesesuaian terhadap faktor lingkungan (tinggi tempat, kelembaban, suhu, dll.), ketersediaan sarana dan prasarana, serta aksesibilitas menuju dan keluar dari lokasi tersebut.

\section{Kelembagaan.}

Penentuan

kelembagaan petani penangkar benih kentang. Kelembagaan petani penangkar harus benar-benar terstruktur dengan baik, sehingga setiap tahapan kegiatan penangkaran benih kentang dapat dipertanggungjawabkan. Setidaknya ada tiga subpenangkaran. Subpenangkaran pertama bertanggung jawab terhadap produksi setek mini dan umbi $G_{0}$. Subpenangkaran kedua bertanggung jawab terhadap produksi umbi $\mathrm{G}_{1}-\mathrm{G}_{2}$. Subpenangkaran ketiga bertanggung jawab terhadap produksi umbi $\mathrm{G}_{3}-\mathrm{G}_{4}$. Pada tahap ini juga akan dilakukan pembenahan dan penguatan kelompok tani. Kegiatan ini dilakukan untuk menyamakan visi tentang konsep kebutuhan akan kelompok, apa itu kelompok, serta aturan apa yang harus ada dan disepakati dalam kelompok. Pelatihan ini penting untuk memberikan pemahaman dan rasa memiliki oleh para petani tentang apa yang mereka lakukan. Diharapkan ada motivasi kebersamaan yang dapat dibangun dan dipertahankan untuk melakukan kegiatan pengembangan penangkaran umbi benih kentang bermutu yang akan di 
introduksikan.

\section{Pelatihan Penangkaran Benih}

Kentang. Pelatihan ini untuk memberikan pengetahuan dasar bagi petani tentang teknologi produksi benih kentang bermutu, pentingnya menggunakan benih kentang bermutu serta keuntungan yang akan diperolehnya, serta perbedaaan antara penggunaan propagul in vitro dengan propagul lainnya. Selain itu akan dilakukan Sekolah Lapang (SL) pengendalian Hama Terpadu (PHT) dan SL pembuatan kompos untuk menyokong prasarana pembenihan kentang bermutu.

Pengadaan Sarana dan Prasarana Pendukung. Sarana dan/atau prasarana pendukung kegiatan pembenihan kentang bermutu perlu dipersiapkan sebaik dan secermat mungkin, agar dapat menyokong kegiatan-kegiatan selanjutnya. Pada tahun pertama ini akan dibuat screen house untuk produksi setek mini dan screen house untuk produksi $\mathrm{G}_{0}$ beserta kelengkapannya.

\section{HASIL DAN PEMBAHASAN}

Kegiatan penangkaran umbi kentang yang telah dilaksanakan tahun 2017 terdiri atas:

- Pengadaan dan perbanyakan planlet kentang

- Pembuatan screen house untuk aklimatisasi dan produksi umbi G0/G1

- Worshop/sosialisasi penangkaran benih kentang
- Sekolah lapang produksi umbi kentang G0/G1

- Pelatihan penguatan kelembagaan petani penangkar kentang.

- Pelatihan sertifikasi benih kentang.

- Pelatihan pembuatan pestisida hayati.

\section{Pengadaan dan Perbanyakan Planlet}

\section{Kentang}

Kegiatan ini bertujuan untuk memperbanyak propagula kentang in vitro sebagai bahan perbanyakan untuk kegiatan selanjutnya, yaitu untuk memproduksi setek mini. Multiplikasi setek in vitro dilaksanakan di Laboratorium Kultur Jaringan Jurusan Budidaya Pertanian Fakultas Pertanian Universitas Andalas, Padang. Dari setiap botol planlet kentang dapat diperoleh setidaknya sepuluh botol planlet yang baru. Ilustrasi multiplikasi setek in vitro dapat dilihat pada Gambar 1.

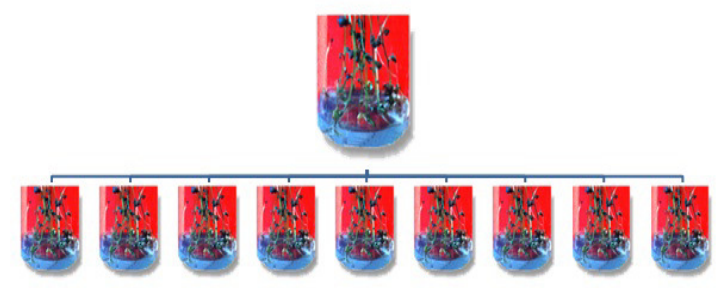

Gambar 1. Multiplikasi Setek In Vitro

Aklimatisasi dilakukan terhadap planlet yang sudah cukup umur untuk diadaptasikan ke lingkungan yang baru (lapang). Media tanam yang digunakan untuk kegiatan aklimatisasi adalah media arang sekam. Sedangkan wadah yang digunakan adalah toples/wadah kue transparan yang berbentuk bulat. Setiap wadah berisi sekitar 100 
planlet kentang, yang berasal dari sekitar 10 botol planlet kentang. Ilustrasi kegiatan aklimatisasi dapat dilihat pada Gambar 2.

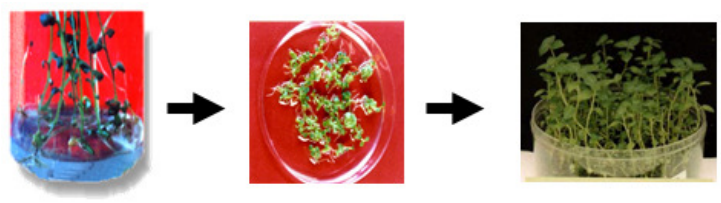

Gambar 2.Tahapan Kegiatan Aklimatisasi Planlet Kentang

\section{Pembuatan Screen House untuk Aklimatisasi} dan Produksi Umbi G0/G1

Kegiatan di lapangan adalah membangun rumah kedap serangga (screen house). Tujuan penggunaan screen house adalah untuk menghindari tanaman kentang dari berbagai jenis cekaman, baik cekaman biotik maupun abiotik, seperti panas, intensitas cahaya matahari yang terlampau tinggi, kekeringan, serta terbebas dari gangguan/serangan hama dan penyakit. Screen house yang telah dibangun terdiri atas 2 (dua) unit untuk aklimatisasi planlet, perbanyakan setek mini, untuk memproduksi umbi mini (umbi G0/G1). Ukuran screen house adalah lebar $5 \mathrm{~m}$ dan panjang $10 \mathrm{~m}$. Screen house dibuat dari rangka kayu dengan dinding terbuat dari screennilon dan atap terbuat dari plastik UV (ultra violet). Bentuk screen house dapat dilihat pada Bentuk screen house dapat dilihat pada Gambar 3.
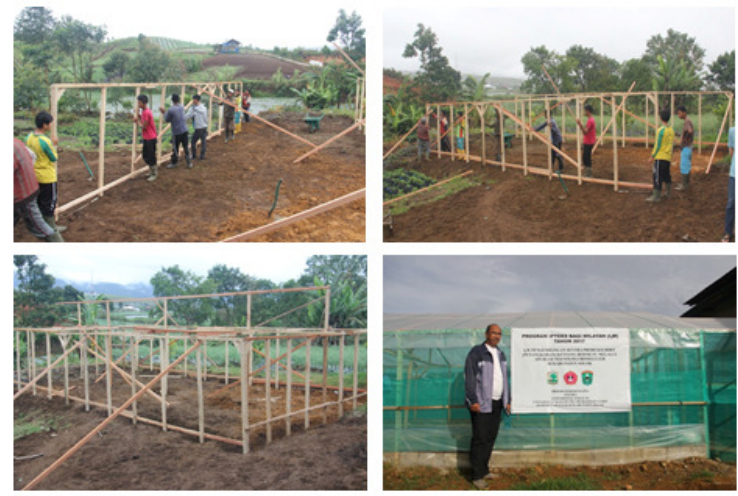

Gambar 3. Pembangunan Screen House untuk Penangkaran Benih Kentang

\section{Workshop Penangkaran Benih Kentang}

\section{Bersama Stake Holders}

Tujuan kegiatan workshop/sosialisasi tentang penangkaran benih kentang bermutu adalah agar para petani mitra dapat memahami kegiatan yang akan mereka laksanakan dan mampu mengadaptasi serta melaksanakan teknologi ini dengan sebaikbaiknya. Petani juga diberi pengetahuan mengenai pentingnya menggunakan bibit kentang bermutu dalam melakukan budidaya kentang mereka. Petani yang terlibat dalam kegiatan ini juga sekaligus dijadikan contoh sebagai penangkar kentang, baik pada level penangkaran kentang G0, G1, dan selanjutnya. Petani terlibat langsung dalam pelaksanaan pembuatan benih kentang pada setiap tahapannya, baik aklimatisasi planlet, produksi G0, dan produksi bibit pada level selanjutnya. Dokumentasi kegiatan dapat dilihat pada Gambar 4. 

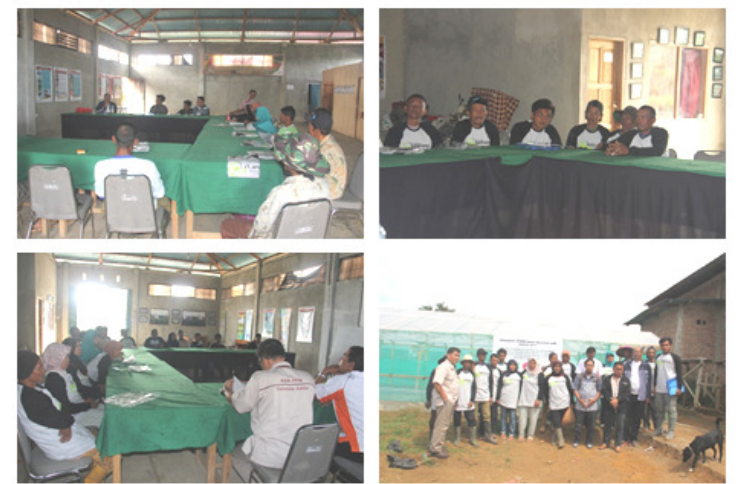

Gambar 4. Workshop Penangkaran Benih

Kentang Bersama Stake Holders

\section{Sekolah Lapang (SL) Produksi Umbi Kentang G0/G1}

Sekolah Lapang (SL) Produksi Umbi Kentang G0/G1 bertujuan untuk melatih para petani calon penangkar benih kentang agar dapat melakukan perbenihan kentang dengan baik sesuai dengan standard dan operasional penangkaran kentang. Dalam kegiatan ini petani yang terlibat diberi pengetahuan dasar tentang persiapan untuk memproduksi umbi G0, meliputi persiapan media tanaman. Bagaimana menyusun media tanaman yang baik, termasuk bagaimana mengatur komposisi media agar diperoleh media yang sesuai untuk pertumbuhan dan perkembangan tanaman kentang. Di samping itu, juga pengajaran yang berkaitan dengan teknologi sterilisasi media, agar segala hama dan penyakit tular tanah dapat dikendalikan dan tidak mengganggu produksi umbi bibit. Dokumentasi kegiatan dapat dilihat pada Gambar 5.
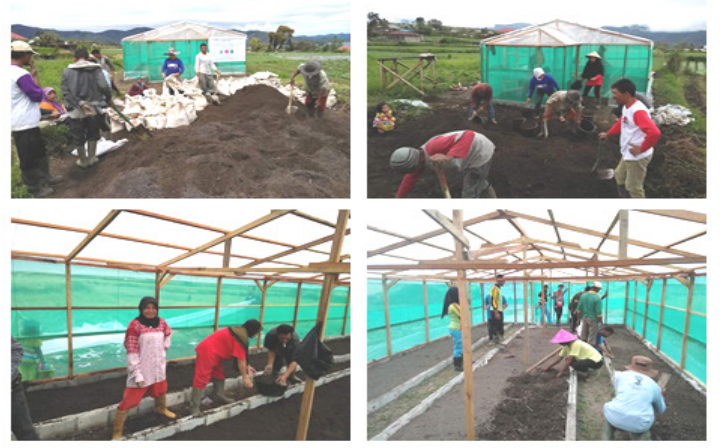

Gambar 5. Sekolah Lapang (SL) Produksi Umbi Kentang G0/G1

\section{Produksi Setek Mini dan Produksi Umbi Kentang G0}

Setek mikro yang telah diaklimatisasi, dalam jangka 2 minggu dapat mulai disetek untuk memperoleh setek mini. Setek mini selanjutnya akan digunakan untuk memproduksi umbi mini (umbi G-0). Ilustrasi perbanyakan setek mini dapat dilihat pada Gambar 6.

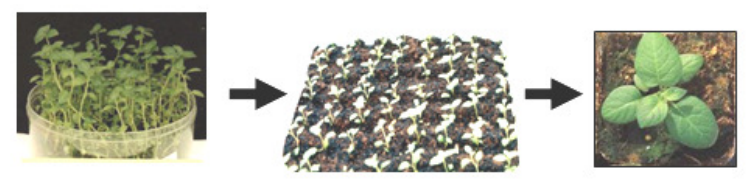

Gambar 6. Perbanyakan Setek Mini

Setek mini yang telah berumur $3-4$ minggu kemudian dipindah tanam (transplanting) ke bedengan-bedengan penanaman dalam rumah kedap serangga. Setek mini ditanam dengan jarak $15 \mathrm{~cm}$ x 20 $\mathrm{cm}$. Tanaman selanjutnya dipelihara dengan melakukan penyiraman secara rutin 2 (dua) kali sehari. Pemupukan dilakukan dengan menggunakan pupuk NPK sesuai takaran dan diberikan sebanyak dua kali. Panen dapat dilakukan setelah daun-daun tanaman berubah warna menjadi kuning dan tanaman 
mulai mengering. Pada saat itu kegiatan penyiraman dihentikan. Contoh bedengan produksi umbi G-0 dapat dilihat pada Gambar 7.
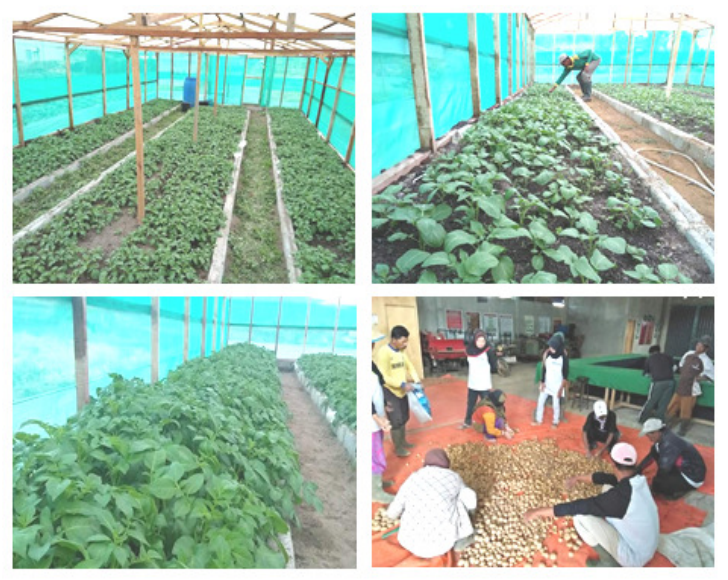

Gambar 7. Produksi umbi G0/G1 dalam Screen House

\section{Pelatihan Penguatan Kelembagaan}

\section{Petani Penangkar Kentang}

Salah satu permasalahan klasik petani di berbagai wilayah adalah; produktivitas rendah, akses informasi teknologi dan pasar rendah, kapasitas permodalah usaha terbatas dan kapasitas SDM petani rendah. Kondisi ini diperburuk oleh fragmentasi lahan dan pengaruh perubahan iklim. Berbagai faktor tersebut menyebabkan daya saing petani rendah dan sulit beranjak dari ketidakberdayaan (unempowerment). Salah satu strategi pemberdayaan petani adalah pembinaan/ pendampingan petani melalui kegiatan penyuluhan secara terpadu melalui pendekatan kelembagaan usaha. Pendekatan kelompok usaha dalam penyuluhan dimaksudkan untuk meningkatkan efektifitas dan efisiensi penyelenggaraan penyuluhan.
Pendekatan kelompok juga dimaksudkan untuk mendorong penumbuhan kelembagaan petani (kelompoktani, gabungan kelompoktani).

Pembinaan kelembagaan petani perlu dilakukan secara berkesinambungan, diarahkan pada perubahan pola pikir petani dalam menerapkan sistem agribisnis. Pembinaan kelembagaan petani juga diarahkan untuk menumbuhkembangkan poktan dan gapoktan dalam menjalankan fungsinya, serta meningkatkan kapasitas poktan dan gapoktan melalui pengembangan kerjasama dalam bentuk jejaring kemitraan usaha.

Dalam rangka meningkatkan kapasitas kelembagaan kelompok tani dalam memproduksi umbi bibit kentang telah dilaksanakan kegiatan pelatihan penguatan kapasitas Kelembagaan kelompok tani. Pelatihan ini dihadiri pengurus dan anggota Kelompok Tani Harapan Baru Alahan Panjang. Materi pelatihan penguatan kelembagaan membahas hal-hal sebagai berikut; (a) pembenahan kelengkapan administrasi kelompok tani; (b) manajemen dan tata kelola organisasi kelompok tani; dan (c) studi banding berupa sosialisasi sucess story beberapa poktan berprestasi. Setelah dilakukan paparan/sosialisasi, acara pelatihan dilanjutkan dengan sesi tanya jawab. Pada sesi ini peserta pelatihan banyak menanyakan hal terkait prospek dan faktor penentu keberhasilan penangkaran benih kentang 
bermutu. Dokumentasi kegiatan dapat dilihat pada Gambar 8.
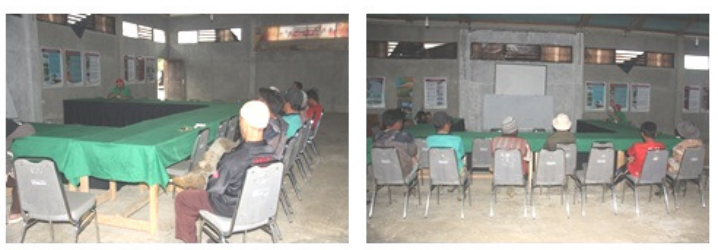

Gambar 8. Pelatihan kelembagaan petani penangkar kentang di Pusat Alih Teknologi dan Pengembangan Kawasan Pertanian Universitas Andalas

\section{Pelatihan Sertifikasi Benih Kentang}

Sertifikasi adalah proses pemberian sertifikat kepada kelompok benih yang sudah lulus pemeriksaan, pengujian laboratorium, dan pengawasan. Benih telah memenuhi persyaratan untuk disalurkan. Tujuan sertifikasi benih kentang adalah:

a. Untuk menjaga kemurnian varietas

b. Untuk mendukung penangkar benih kentang dalam memproduksi benih berkualitas tinggi, yang sehat dan dan ekonomis.

c. Membantu konsumen untuk mendapatkan benih yang berkualitas sesuai dengan harapan.

d. Dengan diterbitkannya sertifikat dan label memberi jaminan bahwa benih kentang telah diperiksa.

Tahapan sertifikasi benih kentang secra keseluruhan dapat dilihat pada bagan sebagai berikut:

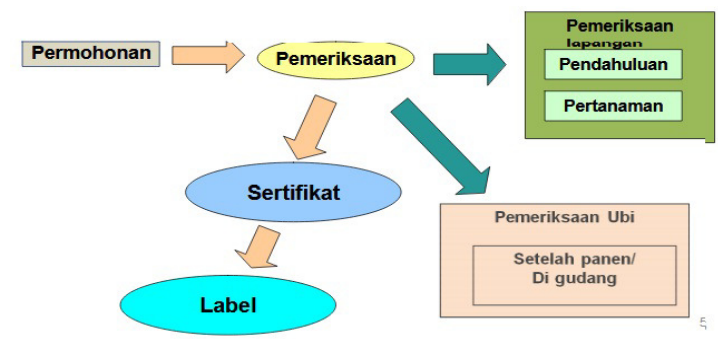

Penangkar benih dapat perorangan, asosiasi, koperasi, pemerintah, perusahaan pemerintah, perusahaan swasta. Adapun persyaratan penangkar adalah:

a. Terdaftar di BPSBTPH.

b. Mempunyai pengatahuan perbenihan

c. Mempunyai benih sumber, lahan dan gudang serta modal

d. Mengikuti peraturan yang berlaku Sedangkan kewajiban yang harus dilakukan sebagai penangkar adalah sebagai berikut:

a. Menyampaikan permohonan sertifikasi benih ke BPSBTP

b. Mengatur dan memelihara lapangan dan gudang

c. Mengikuti pemeriksaan

d. Memberikan informasi yang benar

e. Membuat catatan dan melaporkan kegiatan

f. Menyalurkan benih bersertifikat dan disertai label

g. Bertanggung jawab pada kualitas benih

Hal-hal tersebut di atas yang disampaikan pada saat pelatihan sertifikasi benih kentang. Sehingga para petani sebagai penangkar benih kentang dapat memahami hak dan kewajibannya. Dokumentasi kegiatan pelatihan sertifikasi benih kentang dapat dilihat pada Gambar 9 . 

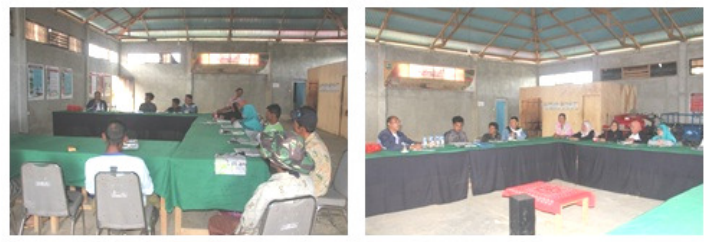

Gambar 9. Pelatihan sertifikasi benih kentang di Pusat Alih Teknologi dan Pengembangan Kawasan Pertanian

Universitas Andalas

\section{Pelatihan Pembuatan Pestisida Nabati}

Secara umum pengendalian hama yang dilakukan petani adalah menggunakan pestisida sintetik. Penggunaan pestisida secara terus menerus tentu akan menimbulkan masalah yang lebih berat yaitu terbunuhnya musuh alami, terjadinya resurjensi, peledakan hama skunder, dan pencemaran lingkungan (Rauf et al., 2000). Untuk mengantisipasi masalah ini, konsep pengendalian hama terpadu (PHT) merupakan alternatif yang tepat, karena PHT bertujuan membatasi penggunaan pestisida sesedikit mungkin tetapi sasaran kualitas dan kuantitas produksi masih dapat dicapai (Sastrosiswoyo dan Oka, 1997)

Sesuai dengan program pertanian berkelanjutan maka teknik pengendalian organisme pengganggu tumbuhan (OPT) mengacu pada pengendalian hama terpadu (PHT). Salah satu komponen utama dalam program ini adalah pengendalian OPT secara nabati. Keuntungan penggunaan pestisida nabati dalam pengendalian penyakit tanaman antara lain: dapat diperbaharui, sumberdaya lokal, dapat diperbanyak dengan teknologi sederhana dan mudah cara aplikasinya. Disamping itu beberapa jenis bakteri sebagai agen hayati punya fungsi ganda, menghasilkan antibiotik, mampu berkompetisi, menghasilkan enzim, membantu ketersediaan hara bagi tanaman, pemacu pertumbuhan tanaman, dan mengimbas ketahanan tanaman terhadap hama dan penyakit tanaman. Untuk itulah makanya diperlukan pengetahuan bagi petani bagaimana caranya membuat dan memformulasikan pestisida hayati. Dokumentasi kegiatan pembuatan pestisida nabati dapat dilihat pada Gambar 10.
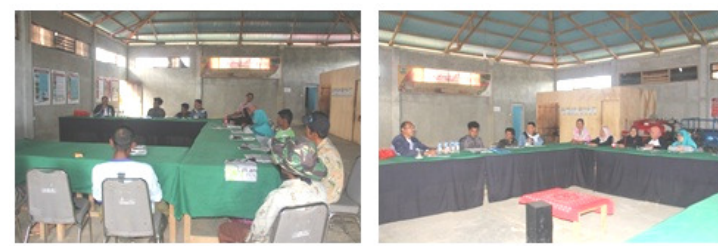

Gambar 10. Pelatihan pembuatan pestisida nabati di Pusat Alih Teknologi dan Pengembangan Kawasan Pertanian Universitas Andalas

\section{KESIMPULAN}

Kegitan IbW tahun pertama (2017) yang telah dilakukan terdiri atas: 1) pengadaan dan perbanyakan planlet kentang, 2) pembuatan screen house untuk aklimatisasi dan produksi umbi G0/G1, 3) workshop/sosialisasi penangkaran benih kentang, 4) sekolah lapang produksi umbi kentang G0/G1, 5) pelatihan penguatan kelembagaan petani penangkar kentang, 6) pelatihan sertifikasi benih kentang, dan 7) pelatihan pembuatan pestisida hayati. 


\section{UCAPAN TERIMAKASIH}

Penelitian ini didanai Direktorat Riset

dan Pengabdian Masyarakat, Direktorat

Jenderal Penguatan Riset dan

Pengembangan, Kementerian Riset,

Teknologi, dan Pendidikan Tinggi sesuai

dengan Perjanjian Penugasan Pelaksanaan

Program Pengabdian kepada Masyarakat

Nomor: 012/SP2H/PPM/DRPM/ 2017, tanggal 3 April 2017 melalui Skema IbW. Untuk itu, kami sampaikan apresiasi dan terimakasih atas kesempatan dan kepercayaannya. Kepada semua pihak yang secara langsung atau tidak langsung terlibat dalam kegiatan penelitian ini juga disampaikan ucapan terima kasih.

\section{REFERENSI}

Anonimous. 2016. Kabupaten Solok Dalam Angka 2016. Badan Pusat Statistik Kabupaten Solok.

Ibrahim. 2017. Waduh, 55 persen biaya produksi petani kentang habis untuk pembibitan. https://jateng.merdeka. com/pertanian/. Diakses 2 November 2017.

Jannah, K. M. 2016. Ketersediaan Benih Kentang Minim, Indonesia Masih Bergantung Impor. https://economy. okezone.com/read/2016/11/23/320/15 49276/. Diakses 2 November 2017.

Nugroho, Y. I. 2011. Impor Menyerang, Petani Meradang. http: //www.agrina-online.com/ redesign2. php? rid $=19 \& \quad$ aid $=3377$. Diakses 23 April 2013.

Putra, A., I. P. C. 2008. Analisis usahatani kentang Sembalun. Balai Pengkajian Teknologi Peranian NTB, Lombok Barat.

Rauf, A., B. M. Shepord, and M.W. Johnson. 2000. Leafminers in vegetales, ornamental plants and weeds in Indonesia: Survey of host crops, species composition and parasitoid. Int.J Pest Manage 46(4); 257-266

Sastrosiswoyo, S. dan I. N. Oka. 1997. Implementasi pengelolaan serangga secara berkelanjutan. Makalah Kongres ke V dan Simposium Entomologi.PEI. Bandung 24-26 Juni 1997. 14 hlmn.

Suliansyah, I 1999. Kecepatan Degenerasi oleh Virus terhadap Kentang Nontransformasi dan Transformasi Coat Protein Selubung. Program Pascasarjana IPB, Bogor. 